\author{
Mariusz Maślak, Ph.D., D.Sc., prof. CUTa)*; Piotr Woźniczka, Ph.D. ${ }^{\text {a) }}$ \\ a) Cracow University of Technology / Politechnika Krakowska \\ * Corresponding author / Autor korespondencyjny: mmaslak@pk.edu.pl
}

\title{
Numerically Simulated Structural Response of a Bearing Steel Frame with Joints of Varying Stiffness to Fully Developed Fire Conditions
}

\author{
Symulowana numerycznie reakcja na pożar rozwinięty stalowej ramy nośnej \\ z węztami o różnej sztywności
}

\begin{abstract}
Aim: This paper examines the responses of load-bearing steel frames to direct fire exposure and the associated impact of the monotonically increasing temperature of its components. For comparative purposes, the authors analysed in detail specific frames with beam-to-column joints differing in rigidity. Depending on whether there are stiffening ribs present and, if so, on where they are located, the fire resistance of the considered structural component is determined by the actual damage patterns. These can be manifested as local instability in the column web or as damage to the column flange or beam flange. The design of the joint is also one of the factors determining the redistribution of internal forces generated in the frame components when subjected to fire conditions.

Methods: The authors identified, discussed and compared the dependencies determining the relationships between the temperature of the frame components, and the bending moments and axial forces induced in these components during a fire. These relationships were identified through a detailed analysis of a numerical example, in which the fire behaviour of three similar steel frames, differing in terms of their beam-to-column joint rigidity, was examined. In the first analysed case, a joint without any ribbing was examined, in the second case, a joint with horizontal ribs, and in the third case, a joint with horizontal and diagonal ribs. The relationships listed above are accompanied by corresponding the relationships specifying the dependencies between steel temperature and frame beam deflection. In addition, the analysis considers flexible supports with different rigidity to model the resistance of the columns to horizontal joint displacement.

Results: It has been shown that the analysed types of the examined frame exhibit substantial differences in their predicted structural responses if the joints used in them and exposed to fire differ in rigidity. The identification of these differences and their qualitative and quantitative description constitute the main objective of this work.

Conclusions: Frame behaviour under fire conditions is determined not only by frame geometry and the size of its structural members, designed to be able to fully bear their respective loads, but also, to the same extent, by the susceptibility to deformation of the bearing structure itself and the joints connecting the component structural members.
\end{abstract}

Keywords: steel frame, fire, temperature, joint susceptibility, displacement, redistribution of internal forces

Type of article: original scientific article

Received: 25.06.2019; Reviewed: 14.08.2019; Accepted: 28.08.2019;

Authors' ORCID IDs:M. Maślak - 0000-0003-3592-429X; P. Woźniczka - 0000-0002-5471-9526;

The authors contributed the equally to this article;

Please cite as: SFT Vol. 53 Issue 1, 2019, pp. 32-45, https://doi.org/10.12845/sft.53.1.2019.2;

This is an open access article under the CC BY-SA 4.0 license (https://creativecommons.org/licenses/by-sa/4.0/).

\section{ABSTRAKT}

Cel: W artykule autorzy analizowali sposób reakcji stalowej ramy nośnej na bezpośrednią ekspozycję ogniową oraz towarzyszący jej monotoniczny wzrost temperatury elementów badanej ramy. W celach porównawczych rozpatrzono ramy z węzłami typu rygiel - słup o różnym stopniu podatności. W zależności od tego, czy węzeł jest użebrowany i jak ewentualne żebra są rozmieszczone, o odporności ogniowej badanego ustroju nośnego decyduje inny sposób zniszczenia. Może to być zarówno lokalna utrata stateczności środnika słupa, jak i zniszczenie pasa rygla lub pasa słupa. Sposób konstrukcji węzła determinuje również schemat redystrybucji sił wewnętrznych generowanych w warunkach pożaru w elementach ramy.

Metody: W pracy zidentyfikowano i porównano odpowiednie zależności specyfikujące relacje pomiędzy temperaturą elementów ramy a indukowanymi w tych elementach momentem zginającym i siłami osiowymi. Zależności te uzyskano po szczegółowej analizie przykładu numerycznego, w którym badano zachowanie w warunkach pożaru trzech odpowiadających sobie ram stalowych, przy czym w każdej z tych ram zastosowano węzły o innej sztywności. W pierwszym przypadku były to węzły z nieużebrowanym środnikiem, w drugim - ze środnikiem użebrowanym jedynie przez wykorzystanie żeber poziomych, w trzecim natomiast - węzły z żebrami poziomymi i żebrem ukośnym. W analizie dodatkowo zróżnicowano sztywność podparcia sprężystego modelującego podatność słupów ramy na poziome przemieszczenie węzłów. 
Wyniki: Uzyskane wyniki potwierdziły oczekiwany wniosek: w początkowej fazie pożaru w ryglach ramy dominuje ściskanie, co przekłada się na rozpychanie węzłów. Ze wzrostem temperatury elementów coraz większego znaczenia nabiera jednak wpływ narastającego ugięcia rygla, co w efekcie generuje postępujący zanik osiowej siły ściskającej. To z kolei powoduje ściąganie węzłów ramy do jej wnętrza. Tego typu ogólny schemat zachowania się ramy w pożarze ma jednak zasadniczo różny przebieg, jeśli tylko węzły ramy wykazują różną sztywność. Specyfikacja tych różnic oraz ich jakościowy i ilościowy opis są podstawowym celem prezentowanej pracy.

Wnioski: Zachowanie się w pożarze rozwiniętym stalowej ramy nośnej warunkowane jest przez jej geometrię oraz rozmiary kształtujących ją elementów konstrukcyjnych o przekrojach zaprojektowanych tak, aby elementy te były zdolne do przenoszenia przyłożonych do nich obciążeń. W równym stopniu istotna jest podatność na deformacje zarówno samego ustroju nośnego, jak i poszczególnych węzłów scalających ten ustrój. Słowa kluczowe: rama stalowa, pożar, temperatura, podatność węzłów, przemieszczenie, redystrybucja sił wewnętrznych Typ artykułu: oryginalny artykuł naukowy

Przyjęty: 25.06.2019; Zrecenzowany: 14.08.2019; Zatwierdzony: 28.08.2019;

Identyfikatory ORCID autorów: M. Maślak - 0000-0003-3592-429X; P. Woźniczka - 0000-0002-5471-9526;

Autorzy wnieśli równy wkład merytoryczny w powstanie artykułu;

Proszę cytować: SFT Vol. 53 Issue 1, 2019, pp. 32-45, https://doi.org/10.12845/sft.53.1.2019.2;

Artykuł udostępniany na licencji CC BY-SA 4.0 (https://creativecommons.org/licenses/by-sa/4.0/).

\section{Introduction}

The fire resistance of a bearing steel frame can only be reliably assessed if the design is considered as a whole rather than in terms of its individual, conceptually isolated components, such as grits or columns. This allows for an equivalent specification of functionally homogeneous structural subcomponents with clearly defined loading diagrams determining how they affect the other components of the structure [1]. The behaviour of bearing steel frames during a fully engulfed fire is determined by their geometric layout and dimensions of their structural components whose sections have been designed to make such components capable of bearing their respective loads. The susceptibility of the bearing structure to deformation is as important as that of its individual joints.

What makes analysing this unique fire design situation even more complex is the fact that this susceptibility varies along with the increase in frame component temperature, which is associated with fire development. However, the restricted freedom of thermal deformations produced by the fire, and resulting from the thermal expansion of steel, causes the structural components of such frames to generate additional internal forces. These forces often act as a decisive factor in the balance of all impacts that determine the ultimate response of the frame to its expected fire exposure, especially when this freedom of deformation is significantly restricted [2]. The goal of this paper is to describe the qualitative and quantitative differences in the behaviour of a typical bearing steel frame substructure, as these differences manifest themselves through different translational susceptibility values describing horizontal loads on the other parts of the frame, and through different rotational susceptibility values for beam-tocolumn joints resulting from their distinct designs (and, consequently, distinct load resistance/stiffening, as a result of employing, or not employing, various types of stiffener ribs).

\section{Wprowadzenie}

Ocena odporności ogniowej stalowej, ramowej konstrukcji nośnej będzie wiarygodna tylko wtedy, gdy szczegółowej analizie poddana zostanie konstrukcja jako całość, nie zaś jedynie pojedyncze, myślowo wyizolowane z niej elementy, takie jak rygle lub słupy. Dopuszcza się przy tym zastępczą specyfikację funkcjonalnie jednorodnych podukładów konstrukcyjnych o jednoznacznie ustalonym schemacie statycznym determinującym sposób oddziaływania na pozostałe części ustroju [1]. Zachowanie się w pożarze rozwiniętym stalowej ramy nośnej warunkowane jest przez jej geometrię oraz rozmiary kształtujących ją elementów konstrukcyjnych o przekrojach zaprojektowanych tak, aby elementy te były zdolne do przenoszenia przyłożonych do nich obciążeń. W równym stopniu istotna jest podatność na deformacje zarówno samego ustroju nośnego, jak i poszczególnych węzłów scalających ten ustrój.

Analizę odniesioną do wyjątkowej sytuacji projektowej pożaru rozwiniętego komplikuje przy tym zmienność tego rodzaju podatności wraz z narastającą z rozwojem pożaru temperaturą elementów ramy. Zawsze jednak ograniczenie swobody realizacji powstających w pożarze odkształceń termicznych będących oczywistym efektem rozszerzalności cieplnej stali skutkuje generowaniem się w elementach konstrukcyjnych rozpatrywanej ramy dodatkowych sił wewnętrznych. Siły tego typu są często czynnikiem decydującym w bilansie wszystkich oddziaływań wpływających na efektywną odpowiedź ramy na prognozowaną dla niej ekspozycję ogniową, zwłaszcza wtedy, gdy stopień ograniczenie swobody deformacji jest odpowiednio duży [2]. Celem niniejszej pracy jest pokazanie jakościowych i ilościowych różnic w zachowaniu się w warunkach pożaru typowego podukładu konstrukcyjnego stalowej ramy nośnej, które ujawniają się przy różnych wartościach podatności translacyjnej ilustrującej oddziaływanie poziome pozostałych części badanej ramy, a także przy różnych wartościach podatności obrotowej węzłów rygiel - słup, wynikających z ich odmiennego ukształtowania (a zatem i usztywnienia wskutek zastosowania lub braku zastosowania w ich konstrukcji różnego typu żeber usztywniających). 


\section{Description of the analysed frame}

This paper will focus on analysing how a specific steel frame substructure behaves during a fire. The steel's geometric layout, loading diagram and imposed loading are presented in figure 1. All frame components are assumed to have been made of steel S235. Fire exposure of the analysed frame results in simultaneous heating of all its components, with the steel temperature distribution being even at any point throughout the fire, both lengthwise and crosswise. Obviously, the reliable temperature at any point during the fire, which is even across all the analysed frame components, varies over time as the fire develops. This approach to fire exposure is, undoubtedly, an oversimplified one. In reality, the temperature of steel components with different crosssections always rises in an irregular fashion, even if such components are exposed to combustion gases with an identical temperature. This is due to the different values of what is known as the exposure rating, which is the ratio of the heated circumference of the analysed component's cross-section to the surface of that cross-section. Nevertheless, this simplification is of no relevance for the purposes of achieving the goal set in this work.

\section{Opis ramy analizowanej w przykładzie}

Przedmiotem szczegółowej analizy jest zachowanie się w pożarze stalowego podukładu ramowego o geometrii, schemacie statycznym i sposobie obciążenia zewnętrznego pokazanych na rycinie 1 . Zakłada się, że wszystkie elementy ramy wykonano ze stali S235. Ekspozycja pożarowa analizowanej ramy skutkuje jednoczesnym ogrzaniem wszystkich składających się na nią elementów, przy czym rozkład temperatury stali jest w każdej chwili pożaru równomierny zarówno po długości tych elementów, jak i w ich przekrojach poprzecznych. Oczywiście miarodajna wartość temperatury w każdej chwili pożaru jednolita dla wszystkich rozpatrywanych składników ramy, zmienia się z czasem wraz z rozwojem pożaru. Taki schemat oddziaływania pożaru stanowi niewątpliwe uproszczenie. W rzeczywistości temperatura elementów stalowych o różnym przekroju poprzecznym narasta zawsze w sposób zróżnicowany, nawet gdy otaczają je gazy spalinowe o identycznej temperaturze. Wynika to z różnych wartości tak zwanego wskaźnika ekspozycji, którego miarą jest stosunek nagrzewanego obwodu przekroju poprzecznego rozpatrywanego elementu do powierzchni tego przekroju. Tego typu uproszczenie jest jednak bez znaczenia dla osiągnięcia celu założonego przez autorów niniejszej pracy.

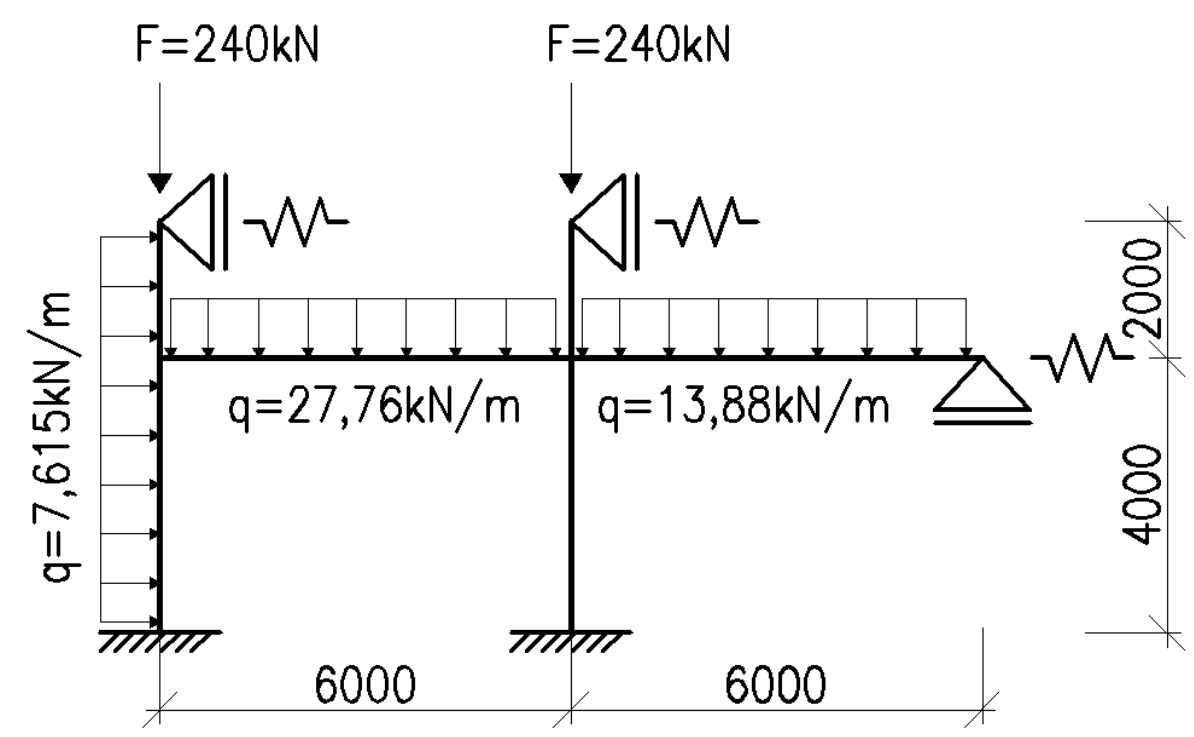

Figure 1. An outline of the frame under consideration

Rycina 1. Schemat ramy rozpatrywanej w pracy

Source: Own elaboration.

Źródło: Opracowanie własne.

The columns of the examined frame were made of cross runner HEA240, while girts were made of I-beam IPE300. As can be seen, the analysed frame used two beam-to-column joint, a unilateral one next to the edge/end left column of the frame, and a bilateral one next to an intermediate column. For comparative purposes, the presented example considers three different design options for these joints. These are (fig. 2):
Słupy ramy rozpatrywanej w przykładzie wykonano z kształtownika HEA240, natomiast rygle - z dwuteownika IPE300. Jak łatwo zauważyć, w analizowanej ramie zastosowano dwa węzły rygiel-słup, odpowiednio jednostronny $w$ sąsiedztwie lewego skrajnego słupa ramy i dwustronny przy słupie pośrednim. W celach porównawczych w niniejszym przykładzie zakłada się trzy różne warianty konstrukcji tego typu węzłów. Są to kolejno (ryc. 2): 
- joint "A" (fig. 2a) - a fillet-welded joint with no web stiffeners,

- joint "B" (fig. 2b) - joint "A" with additional horizontal web stiffeners placed at the levels corresponding to beam flanges,

- joint "C" (fig. 2C) - joint "B" with an additional stiffener placed diagonally to the other stiffeners.

The initial stiffness of each joint type was determined on the basis of separate calculations. The computed values were as follows:

$$
\begin{aligned}
& \text { - for joint "A": } S_{i n i}^{A}=14753 \frac{\mathrm{kN} \cdot \mathrm{m}}{\mathrm{rad}}, \\
& \text { - for joint "B": } S_{i n i}^{B}=31950 \frac{\mathrm{kN} \cdot \mathrm{m}}{\mathrm{rad}}, \\
& \text { - for joint "C": } S_{i n i}^{C}>>103000 \frac{\mathrm{kN} \cdot \mathrm{m}}{\mathrm{rad}},
\end{aligned}
$$

which means that this joint is nominally rigid.
- węzeł typu "A" (ryc. 2a) - jest to węzeł spawany na spoiny pachwinowe, bez zastosowania jakichkolwiek żeber usztywniających środnik słupa,

- węzeł typu "B” (ryc. 2b) - jest to węzeł typu „A" uzupełniony o poziome żebra usztywniające środnik słupa, umieszczone w poziomach odpowiadających położeniu pasów rygli,

- węzeł typu "C" (ryc. 2c) - jest to węzeł typu "B" uzupełniony o dodatkowe żebro zorientowane diagonalnie względem poprzednich.

Początkową sztywność poszczególnych wariantów węzła wyznaczono na podstawie odrębnych obliczeń. Otrzymano odpowiednio:

- dla węzła typu „A": $S_{i n i}^{A}=14753 \frac{\mathrm{kN} \cdot \mathrm{m}}{\mathrm{rad}}$,

- dla węzła typu "B": $S_{i n i}^{B}=31950 \frac{\mathrm{kN} \cdot \mathrm{m}}{\mathrm{rad}}$,

- dla węzła typu "C": $S_{i n i}^{C}>>103000 \frac{\mathrm{kN} \cdot \mathrm{m}}{\mathrm{rad}}$,

co oznacza, że węzeł jest nominalnie sztywny.

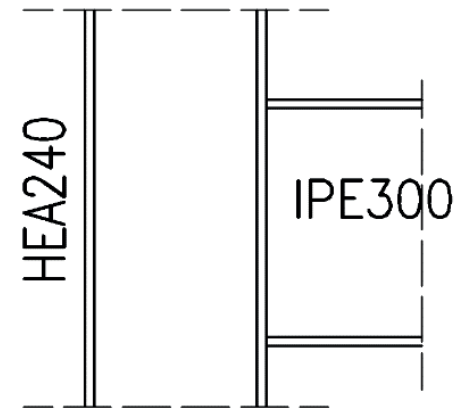

a)

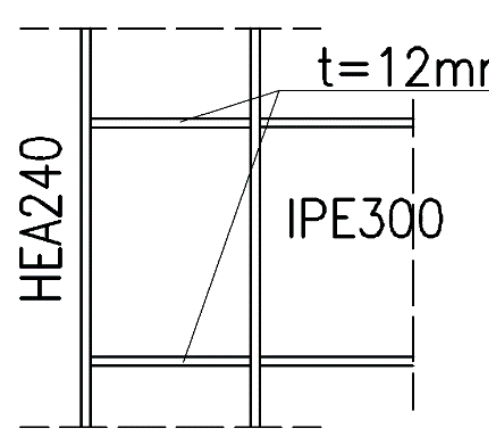

b)

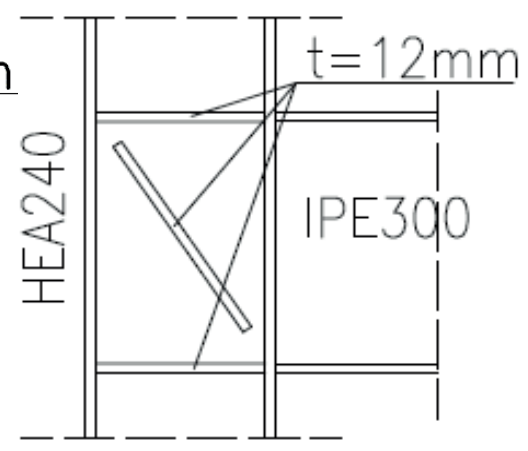

c)

Figure 2. Joint types under consideration. From the left: a) joint " $A$ " b) joint " $B$ " b) joint “ $C$ "

Rycina 2. Typy węzłów analizowane w tekście. Od lewej: a) węzeł typu "A" b) węzeł typu „B" c) węzeł typu "C"

Source: Own elaboration.

Źródło: Opracowanie własne.

The columns of the examined frame were rigidly fixed in the foundation. Their upper ends can only move freely vertically, which allows their unlimited thermal extension (fig. 1). It was also assumed that all frame components were effectively secured against lateral torsional buckling throughout the fire so that the frame would only be subject to in-plane buckling while any out-of-plane buckling would be disregarded. The effects of the other parts of the frame on the structural subsystem, as analysed here in detail, were modelled by adding to all the supports considered as roller supports the springs placed horizontally to constrain horizontal movement (fig. 1). This way the frame's girt is no longer able to freely extend as a result of heat, while the upper ends of both columns are also, to some extent, able to move horizontally. This detailed analysis considers three inde-
Słupy badanej ramy są sztywno utwierdzone w fundamentach. Ich górne końce mają możliwość swobodnego przemieszczania się jedynie wkierunku pionowym, co pozwala na ich nieskrępowane wydłużenie termiczne (ryc. 1). Założono również, że wszystkie elementy ramy są przez cały czas pożaru skutecznie zabezpieczone przed zwichrzeniem, tak że rama będzie deformować się jedynie w swojej płaszczyźnie (in-plane buckling), natomiast ewentualne deformacje w kierunku prostopadłym do tej płaszczyzny (w tym także out-of-plane buckling) będą pomijane. Oddziaływanie pozostałych części ramy na rozpatrywany szczegółowo podukład konstrukcyjny w niniejszym przykładzie zamodelowano przez dodanie do wszystkich podpór traktowanych jako więzy przegubowo przesuwne usytuowanych poziomo sprężyn ograniczających swobodę przemieszczeń poziomych (ryc. 1). W ten sposób rygiel ramy traci 
pendent design scenarios that differ in terms of the stiffness of the springs installed. These are:

- Scenario "a", in which the stiffness of all horizontal springs is assumed to be infinite, so $k_{i}^{a}=\infty$

- Scenario " $b$ ", in which the stiffness of each of the horizontal springs is assumed to be finite at $k_{i}^{b}=0.58 \frac{\mathrm{N}}{\mathrm{mm}^{3}}$,

- Scenario "c", in which the stiffness of each of the horizontal springs is assumed to be finite, but lower than in Scenario "b", at $k_{i}^{c}=0.38 \frac{\mathrm{N}}{\mathrm{mm}^{3}}$.

\section{Behaviour of the examined frame during a fully engulfed fire}

\section{Description of the material used}

In order to examine how the above-mentioned frame behaves when directly exposed to fire, given these different beamto-column design options and scenarios for the structural steel of which all frame components were made, the classical elasticelliptical-perfectly plastic model of behaviour during a fire was adopted in line with EN 1993-1-2 recommendations [3]. This is associated with a specific approach that takes into consideration the joint stiffness resulting from the increasing temperature of joint components. This reduction was quantified in proportion to the decreasing linear elasticity of steel $E_{a, \Theta}$, where $\Theta$ is the temperature of steel.

\section{Frame deformation analysis}

The deformations resulting from the exposure of the frame to a fire are usually similar in qualitative terms, regardless of the joint design option or scenario. Where they differ significantly, however, is their expected movement. Figure 3 shows examples of deformations produced at successive moments throughout the fire for joints " $\mathrm{C}$ " and scenario "a" (solution " $\mathrm{C}-\mathrm{a}$ "). The computations were made using ANSYS software [4].

It can be easily noticed that during the initial stage of the fire, as the steel temperature rises, the girt is made to expand and push the columns away which, in turn, generates axial compression force in that girt. But, over time, as temperature becomes much higher, the flexural stiffness of the girt is so low that its resistance to growing deflection crumbles. This large deflection, in turn, causes the joints within the frame to be pulled inwards, which compensates more and more effectively for the axial compression of the girt. Finally, while this girt, although significantly weakened during the fire, is still able to transfer loads, the axial compression force that has been previously generated inside it dissipates completely and the girt enters the axial ten- pełną swobodę realizacji termicznie indukowanego wydłużenia, natomiast górne końce obu słupów ramy zyskują ograniczoną możliwość przemieszczania się również w kierunku poziomym. W szczegółowej analizie rozpatruje się trzy niezależne sytuacje projektowe różnicowane sztywnością założonych sprężyn. Są to kolejno:

- sytuacja "a", dla której zakłada się, że sztywność wszystkich poziomych sprężyn jest nieskończona, a zatem $k_{i}^{a}=\infty$,

- sytuacja „b”, dla której przyjęto, że sztywność każdej z założonych poziomych sprężyn jest skończenie duża

i wynosi $k_{i}^{b}=0,58 \frac{\mathrm{N}}{\mathrm{mm}^{3}}$,

- sytuacja "c", dla której przyjęto, że sztywność każdej z założonych poziomych sprężyn jest skończona, ale mniejsza niż w sytuacji „b", i wynosi jedynie $k_{i}^{c}=0,38 \frac{\mathrm{N}}{\mathrm{mm}^{3}}$.

\section{Zachowanie się badanej ramy w pożarze rozwiniętym}

\section{Charakterystyka zastosowanego materiału}

W celu zbadania, jak zdefiniowana powyżej rama zachowa się w warunkach bezpośredniej ekspozycji ogniowej, przy różnych wariantach konstrukcji węzłów rygiel-słup i w różnych sytuacjach projektowych, dla stali konstrukcyjnej, z której zostały wykonane wszystkie elementy ramy, założono klasyczny sprężysto-eliptyczno-idealnie plastyczny model zachowania się w pożarze, zgodny z rekomendacjami normy EN 1993-1-2 [3]. Z założeniem tym wiąże się sposób uwzględniania redukcji sztywności węzłów, będącej skutkiem narastającej temperatury ich składników. Redukcję tę kwantyfikowano proporcjonalnie do malejącej wartości współczynnika liniowej sprężystości stali

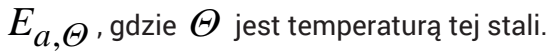

\section{Analiza deformacji ramy}

Jakościowy charakter deformacji będących skutkiem oddziałującej na ramę ekspozycji ogniowej jest na ogół podobny, niezależnie od tego, jaki wariant konstrukcji węzła jest zastosowany oraz która z wyspecyfikowanych powyżej sytuacji projektowych jest brana pod uwagę. Różnią się za to znacząco wartości prognozowanych przemieszczeń. Na rycinie 3 pokazano przykładowe deformacje uzyskane $w$ kolejnych momentach pożaru po zastosowaniu węzłów typu "C" oraz przy analizie sytuacji projektowej „a" (rozwiązanie "C-a"). Obliczenia numeryczne przeprowadzono przy pomocy programu ANSYS [4].

Łatwo zauważyć, że w początkowej fazie pożaru rygiel ramy wydłużający się wraz z narastającą temperaturą stali rozpycha słupy, co skutkuje generowaniem się w tym ryglu osiowej siły ściskającej. Z czasem jednak, przy znacząco wyższej temperaturze elementów, sztywność giętna rygla jest już na tyle mała, że słabnie jego opór wobec rosnącego przyrostu ugięcia. Duże ugięcia powodują z kolei ściąganie węzłów ramy do wewnątrz, a to coraz efektywniej kompensuje osiowe ściskanie rygla. W końcu, o ile rozpatrywany rygiel - bardzo już osłabiony w po- 
sion phase. Obviously, girt deflection during a fire depends on the design of beam-to-column joint within the frame. The differences in deflection between solutions " $\mathrm{A}-\mathrm{a}$ ", "B-a" and " $\mathrm{C}-\mathrm{a}$ " are presented in figure 4 . żarze - jest nadal zdolny do przenoszenia obciążeń, generowana w nim wcześniej osiowa siła ściskająca całkowicie zanika i rozpoczyna się faza jego osiowego rozciągania. Oczywiście, realizowane w pożarze ugięcie rygla zależy od tego, jak w rozpatrywanej ramie skonstruowane są węzły rygiel-słup. Różnice w wartościach ugięcia otrzymanych kolejno dla rozwiązań „A-a”, „B-a” $\mathrm{i}$ „C-a” zaprezentowano na rycinie 4.

$\Theta=20^{\circ} \mathrm{C}$

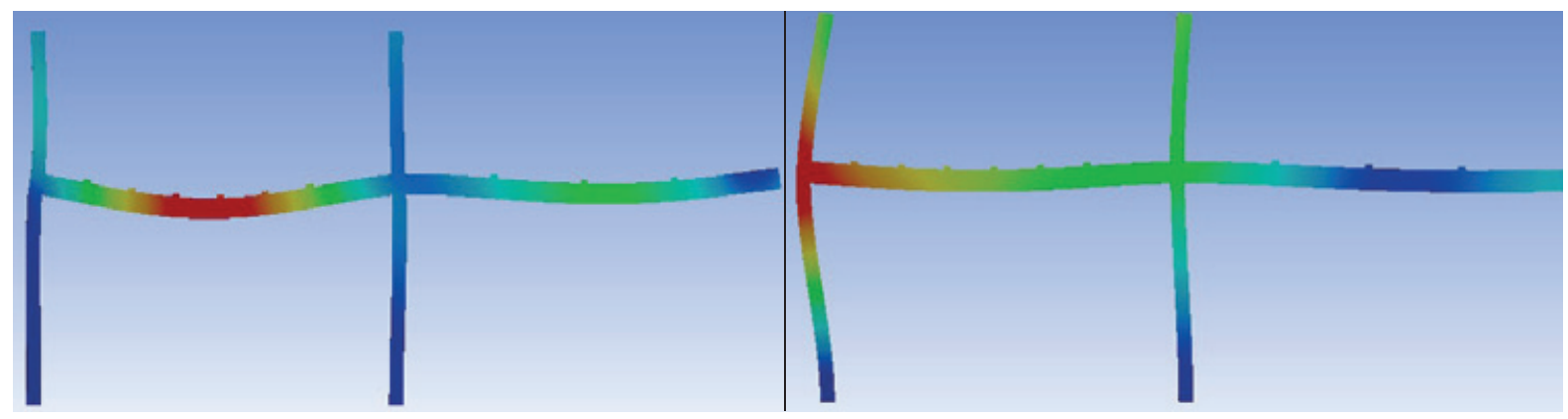

$\Theta=400^{\circ} \mathrm{C}$

$\Theta=600^{\circ} \mathrm{C}$

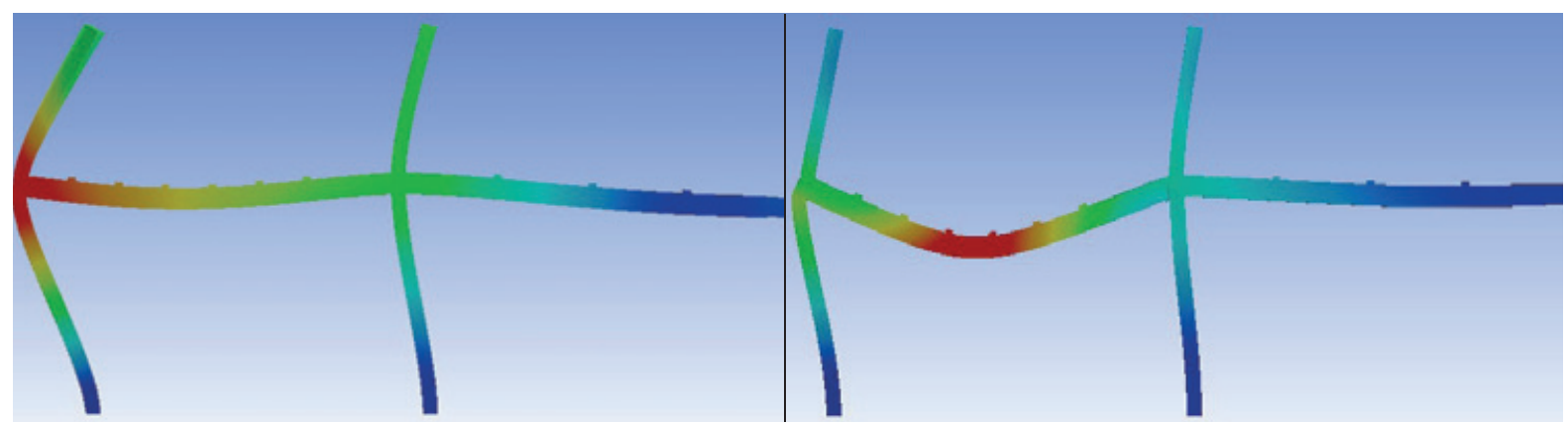

Figure 3. Deformations of the frame substructure under consideration, occurring at subsequent stages of the fire, based on analysing solution "C-a" (described in the text)

Rycina 3. Deformacje rozpatrywanego w przykładzie podukładu ramowego uzyskane w kolejnych chwilach pożaru przy analizie rozwiązania "C-a" (opis w tekście)

Source: Own elaboration.

Źródło: Opracowanie własne.

As can be seen, during the initial stage of the fire, girt deflection, originally determined for room temperature, drops significantly. This is mainly due to the thermal expansion of columns. Over time, girt deflection starts growing rapidly. It is important to note that if the frame uses relatively flexible joints " $A$ " (solution "A-a"), the above-mentioned increase in deflection is virtually nonexistent. Indeed, at a component temperature of approximately $\Theta=\Theta_{C r}^{A-a} \approx 500^{\circ} \mathrm{C}$, the frame reaches its specific fire resistance limit state. The damage pattern characteristic for this joint type will be presented later in the paper (fig. 9). At this point it is only important to note that the critical temperature of the examined frame associated with its joints " $\mathrm{B}$ " (solution
Jak widać, w początkowej fazie pożaru ugięcie rygla wyznaczone pierwotnie dla warunków temperatury pokojowej znacząco maleje. Jest to głównie skutek termicznego wydłużania się słupów. Z czasem jednak ugięcie rygla zaczyna gwałtownie narastać. Trzeba jednak podkreślić, że w przypadku zastosowania w ramie stosunkowo podatnych węzłów typu "A" (rozwiązanie „A-a") wspomniany powyżej przyrost ugięcia w zasadzie nie został zrealizowany. W temperaturze elementów zbliżonej do $\Theta=\Theta_{C r}^{A-a} \approx 500^{\circ} \mathrm{C}$ taka rama osiągnęła bowiem specyfikowany dla niej stan graniczny nośności ogniowej. Sposób zniszczenia charakterystyczny dla tego typu węzła zostanie pokazany w dalszej części pracy (ryc. 9). W tym miejscu na- 
"B-a") and " $\mathrm{C}$ " (solution " $\mathrm{C}-\mathrm{a}$ ") proved to be much higher and was $\Theta_{C r}^{B-a} \approx 630^{\circ} \mathrm{C}$ and $\Theta_{C r}^{C-a} \approx 633^{\circ} \mathrm{C}$, respectively. Similar critical temperature values for solutions "B-a" and "C-a" result from their comparable damage patterns, as illustrated in figures 10 and 11. leży jedynie zwrócić uwagę na fakt, że temperatura krytyczna badanej ramy kojarzona z zastosowanymi w niej węzłami typu "B" (rozwiązanie „B-a") i typu „C" (rozwiązanie "C-a") okazała się być znacznie wyższa i wyniosła odpowiednio $\Theta_{C r}^{B-a} \approx 630^{\circ} \mathrm{C}$ i $\Theta_{c r}^{C-a} \approx 633^{\circ} \mathrm{C}$. Podobne wartości temperatury krytycznej otrzymane dla rozwiązań „B-a” i "C-a” są następstwem zbliżonego sposobu zniszczenia węzła w pożarze, co zilustrowano na rycinach 10 i 11 .

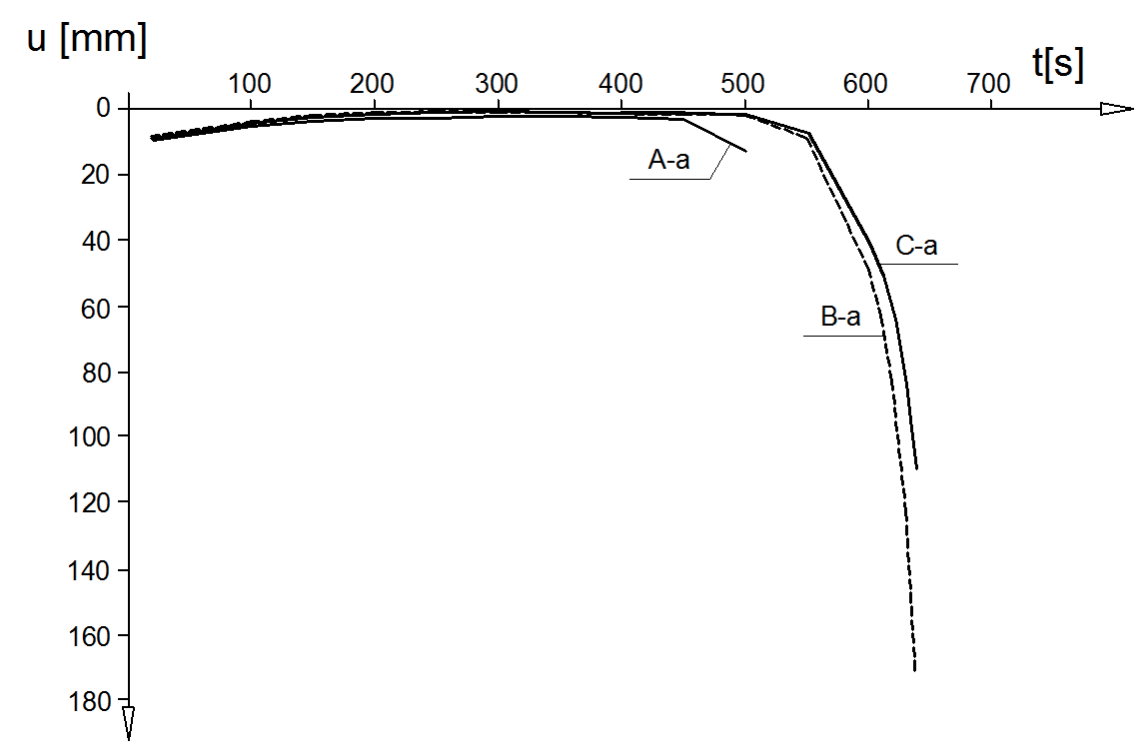

Figure 4. Deflections at the midspan of the girt of the frame under consideration, obtained for solutions "A-a," "B-a" and "C-a" (described in the text) Rycina 4. Ugięcia w środku rozpiętości rygla rozpatrywanej ramy otrzymane dla rozwiązań „A-a”, „B-a” i „C-a” (opis w tekście)

Source: Own elaboration.

Źródło: Opracowanie własne.

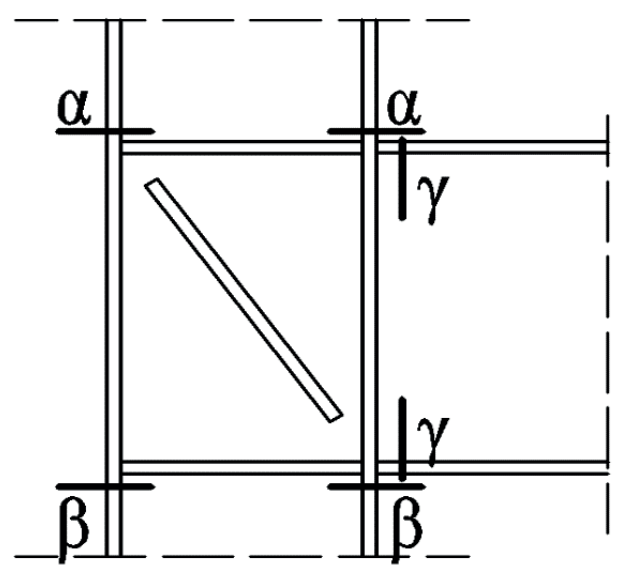

Figure 5. Location of cross-sections $\alpha-\alpha, \beta-\beta$ and $\gamma-\gamma$, respectively, for which the steel-temperature-dependent values of the internal forces induced by the fire in the end column and the adjacent grid of the frame under consideration were determined Rycina 5. Lokalizacja przekrojów poprzecznych, dla których odpowiednio $\alpha-\alpha, \beta-\beta$ i $\gamma-\gamma$ określano zależne od temperatury stali wartości sił przekrojowych generowanych w pożarze w skrajnym słupie i sąsiadującym z nim ryglu rozpatrywanej ramy Source: Own elaboration

Źródło: Opracowanie własne. 


\section{Redistribution of internal forces within the frame}

Let us now examine the effects of unilateral beam-to-column joint design on the internal forces generated during a fire within selected cross-sections of such joints, located at the edge column of the examined frame. All results shown in the Figures below (figs. 6 and 7) refer to the design scenario "a" with infinitely stiff springs that restrict the horizontal movement of supports. The positions of the cross-sections for which the successive values of internal forces were specified, which changed as steel temperature increased, are shown in figure 5 . These crosssections are marked as $\alpha-\alpha, \beta-\beta$ and $\gamma-\gamma$, respectively. It is important to note that the separation of these crosssections from the point identified as the crossing of the axes of the elements that meet at the joint (known as the offset) does not make it possible to formally verify the balance of the joint for any specific steel temperature.

\section{Redystrybucja sił wewnętrznych w ramie}

W dalszych rozważaniach zbadany zostanie wpływ konstrukcji jednostronnego węzła rygiel-słup na siły wewnętrzne generowane podczas pożaru w wybranych przekrojach poprzecznych tegoż węzła, zlokalizowanego przy skrajnym słupie ramy rozpatrywanej w przykładzie. Wszystkie wyniki pokazane na rysunkach zamieszczonych poniżej (ryc. 6 i 7) dotyczą sytuacji projektowej „a" z nieskończenie sztywnymi sprężynami ograniczającymi poziome przemieszczenia podpór. Usytuowanie przekrojów poprzecznych, dla których specyfikowano kolejne wartości sił przekrojowych, zmieniające się wraz z narastającą temperaturą stali, pokazano na rycinie 5. Przekroje te oznaczono odpowiednio symbolami: $\alpha-\alpha$, $\beta-\beta$ i $\gamma-\gamma$. Należy zaznaczyć, że odseparowanie przyjętych przekrojów względem punktu identyfikowanego ze skrzyżowaniem osi elementów łączonych w węźle (czyli tak zwany "offset”) nie daje możliwości formalnej weryfikacji stanu równowagi tego węzła przy założonej wartości temperatury stali.

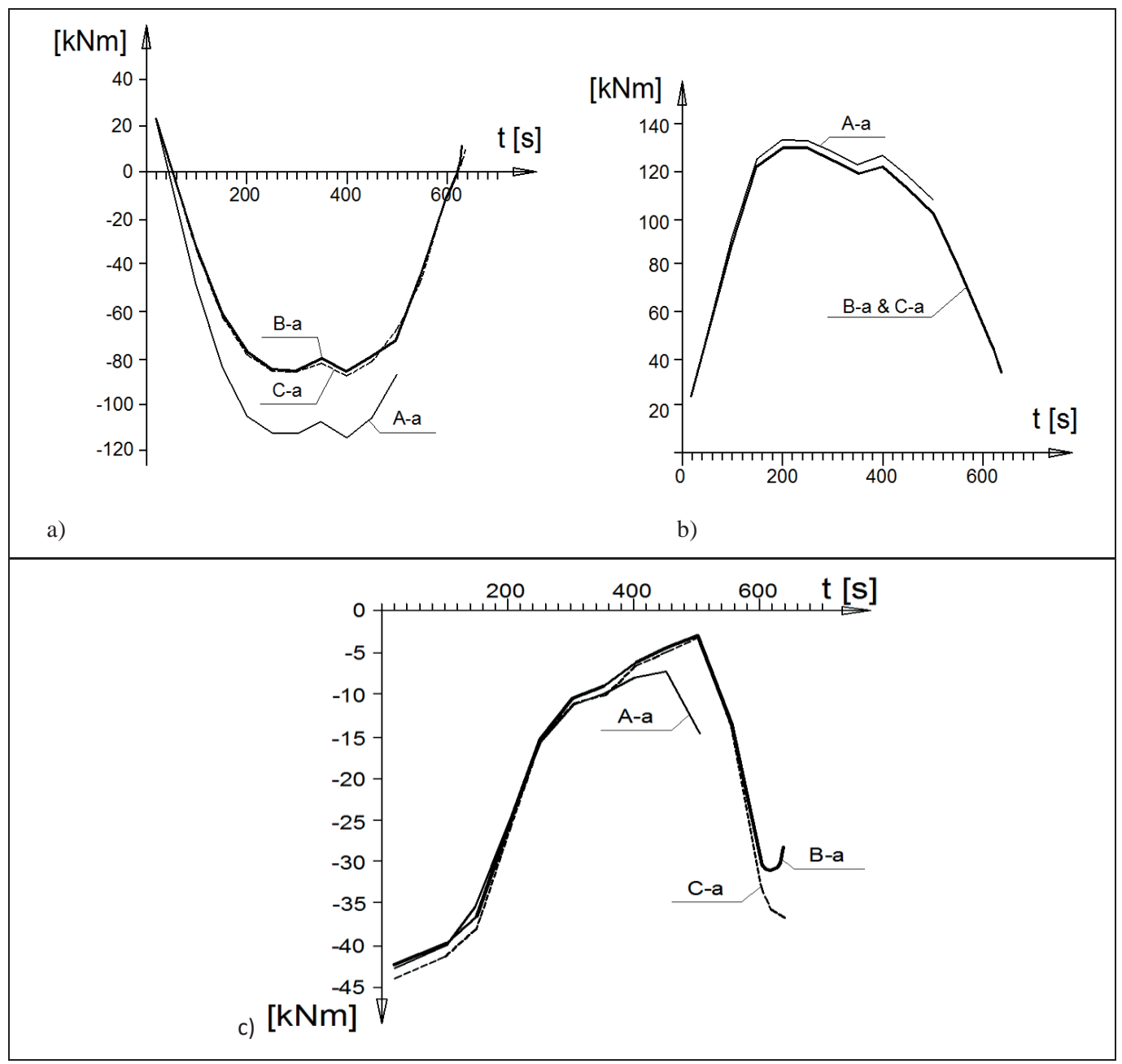

Figure 6. The relationship between steel temperature and the values of bending moments induced by the fire in the end beam-to-column joint of the frame under consideration; results obtained for scenario "a", in: a) $\alpha-\alpha$ cross-section b) $\beta-\beta$ cross-section c) $\gamma-\gamma$ cross-section, respectively Rycina 6. Zależności pomiędzy temperaturą stali i wartościami momentów zginających generowanych w pożarze w skrajnym węźle ryqiel-słup ramy rozpatrywanei w przykładzie. Wyniki uzyskane dla sytuacji projektowej „a”, odpowiednio: a) w przekroju $\alpha-\alpha$ b) w przekroju $\beta-\beta$ c) w przekroju $\gamma-\gamma$

Source: Own elaboration.

Źródło: Opracowanie własne. 
In this paper, the results for the fire-scenario-specific detailed analysis of the redistribution of the internal forces produced within the components of the examined frame substructure are presented starting from diagrams showing changes in bending moments, as identified for each joint type (joints "A", "B" and "C"), in cross-sections $\alpha-\alpha$ (fig. 6a), $\beta-\beta$ (fig. $6 \mathrm{~b}$ ), and $\gamma-\gamma$ (fig. 6c), respectively. As can be seen, for the imposed loading and loading diagram of the frame shown in figure 1, prior to the fire (i.e., for $\Theta=20^{\circ} \mathrm{C}$ ), large bending moments were identified mainly within the girt in the examined substructure, while in columns, both above and below the girt, they remained relatively small. However, during the initial stage in the fire, as the columns expanded and the girt was compressed as a result of increasing temperature, the columns' bending moments increased rapidly, which also caused reduced girt bending. Ultimately, however, when steel temperature was high enough, the resistance of the increasingly hotter columns to the thermal expansion of the girt became significantly weaker. At the same time, the flexural stiffness of the girt itself decreased markedly. This caused girt deflections to become less and less restricted, and consequently more and more rapid. As a result of all this, the degree of column bending gradually decreased, causing girt deflections to grow. The pattern described above represents a typical redistribution of internal forces across frame components during a fire. However, it is important to bear in mind that the bending moments identified for structural components at increasing steel temperature correspond to decreasing loadbearing capacity of such components. This is mainly due to the steel-specific yield strength, which is reduced as fire develops. A comparison of the diagrams presented in figure 6 shows that the redistribution of the bending moments during a fire was not that different for joint " $\mathrm{B}$ " and " $\mathrm{C}$ " frames (fig. 2). Nonetheless, there were significant differences, both qualitative and quantitative, when joint " $\mathrm{A}$ " was used in the same structure. In the presented diagrams, this scenario corresponds to the significantly lower critical temperature achieved by the analysed frame as it reaches its fire resistance limit state. Similar conclusions can be drawn by comparing how the axial force generated in the girt is redistributed for joints " $\mathrm{A}$ ", " $\mathrm{B}$ ", and " $\mathrm{C}$ " (fig. 7).

As can be seen, the way the stiffness of the joint used in the frame impacts on the fire-scenario-specific redistribution of internal forces is not significant. This is particularly visible when the joint, compared to other joint designs, is so flexible that it causes the fire resistance of the frame to drop significantly as a result of being heated up. This is what happens when joint " $\mathrm{A}$ " is used in the frame. What seems to be much more important, from the point of view of estimating the effective load-bearing capacity for fire conditions, is the impact of the frame's flexibility level on horizontal movement. In the analysed example, such flexibility varies between the above-mentioned design scenarios, i.e. "a", "b", and "c", which correspond to different stiffness parameters of the applied springs. Figure 8 shows the redistribution of bending moments produced for different design scenarios (solutions "C-a", "C-b", and "C-c") when joint " $\mathrm{C}$ " was used in the frame. Interestingly, the differences in the redistribution of internal forces appear significant only during the first stage of
W niniejszej pracy zestawienie wyników uzyskanych ze specyfikowanej dla sytuacji pożaru szczegółowej analizy redystrybucji sił wewnętrznych indukowanych w elementach rozpatrywanego podukładu ramowego rozpoczyna się od wykresów prezentujących zmiany momentów zginających zidentyfikowanych dla poszczególnych rodzajów węzłów (typu „A", „B" i „C") odpowiednio w przekrojach $\alpha-\alpha$ (ryc. 6a), $\beta-\beta$ (ryc. 6b) i $\gamma-\gamma$ (ryc. 6c). Jak widać, przy obciążeniach zewnętrznych i schemacie statycznym ramy pokazanych na rycinie 1, przed zainicjowaniem pożaru (to znaczy dla $\Theta=20^{\circ} \mathrm{C}$ ), duże momenty zginające były identyfikowane głównie w ryglu rozpatrywanego podukładu - w słupach, zarówno powyżej jak i poniżej rygla, pozostawały na stosunkowo niskim poziomie. Jednakże, w początkowej fazie pożaru, rozpychanie słupów i narastające ze wzrostem temperatury stali ściskanie rygla spowodowało szybki wzrost wartości momentów zginających słupy, co skutkowało równoczesnym osłabieniem zginania rygla. W końcu jednak, przy odpowiednio wysokiej temperaturze stali, opór stawiany termicznemu wydłużaniu się rygla przez coraz silniej rozgrzane słupy uległ znacznemu osłabieniu. W tym samym czasie wyraźnie zmalała również sztywność giętna samego rygla. Skutkowało to coraz słabiej krępowanym - a więc i coraz bardziej gwałtownym - przyrostem ugięcia tego rygla. Wszystko to spowodowało zmniejszanie się stopnia zginania słupów i towarzyszący temu zjawisku powrót do coraz silniejszego zginania rygla. Przedstawiony powyżej schemat odpowiada typowemu przebiegowi redystrybucji sił przekrojowych w elementach ramy w warunkach pożaru. Należy jednak mieć na względzie fakt, że momentom zginającym identyfikowanym w elementach konstrukcyjnych przy coraz wyższej temperaturze stali odpowiada coraz mniejsza wartość nośności tych elementów. Wynika ona głównie z postępującej wraz z rozwojem pożaru redukcji granicy plastyczności specyfikowanej dla tej stali. Porównanie wykresów zaprezentowanych na rycinie 6 pozwala na stwierdzenie, że przebieg redystrybucji momentów zginających w warunkach pożaru nie różnił się znacząco w sytuacji, gdy w rozpatrywanej ramie zastosowano węzeł typu "B" i węzeł typu „C” (ryc. 2). Różnica, zarówno ilościowa jak i jakościowa, była jednak wyraźnie widoczna w przypadku zastosowania w tym samym ustroju węzła typu „A”. Sytuacji tej odpowiada bowiem na prezentowanych wykresach znacząco niższa wartość temperatury krytycznej kojarzonej z osiągnięciem przez analizowaną ramę stanu granicznego nośności ogniowej. Do analogicznych wniosków dochodzi się również, porównując zidentyfikowany kolejno dla węzłów typu „A", typu „B" i typu „C" sposób redystrybucji siły podłużnej generowanej w ryglu (ryc. 7).

Jak widać, wpływ sztywności węzła zastosowanego w ramie na specyfikowany dla sytuacji pożaru sposób redystrybucji sił przekrojowych nie jest znaczący. Uwidacznia się on szczególnie wtedy, gdy węzeł ten, w stosunku do porównywanych z nim węzłów o innej konstrukcji, jest na tyle podatny, że w efekcie nagrzewania determinuje wyraźne obniżenie odporności ogniowej badanej ramy. Tak dzieje się w przypadku zastosowania w ramie węzła typu „A". Znacznie bardziej istotny z punktu widzenia prognozy efektywnej nośności ramy szacowanej dla warunków pożaru wydaje się wpływ stopnia podatności tej ramy na przemieszczenia poziome. Podatność tego typu w analizowanym przykładzie różnicowana jest przez wyszczególnione powyżej sytuacje projektowe, odpowiednio „a", „b" i „c", 
the fire, when the temperature of the frame components is lower than $\Theta \approx 400^{\circ} \mathrm{C}$. At higher temperatures, these differences seem to disappear, which suggests that, as yield strength loss becomes accelerated in structural steel, the different degrees of frame susceptibility to horizontal deformations become less relevant. odpowiadające kolejno przyjętym wartościom sztywności założonych sprężyn. Na rycinie 8 zaprezentowano przebieg redystrybucji momentów zginających uzyskanych po zastosowaniu w badanej ramie węzła typu "C" dla kolejnych rozpatrywanych w przykładzie sytuacji projektowych (rozwiązania „C-a”, „C-b" i „C-c"). Co ciekawe, różnice $w$ przebiegu redystrybucji sił przekrojowych są tu znaczące w zasadzie jedynie w pierwszej fazie pożaru, gdy temperatura elementów ramy nie przekracza wartości $\Theta \approx 400^{\circ} \mathrm{C}$. W temperaturze wyższej wydają się zanikać, co świadczy o tym, że przy coraz szybciej postępującej redukcji granicy plastyczności stali konstrukcyjnej zróżnicowanie stopnia podatności ramy na deformacje poziome traci swe istotne znaczenie.

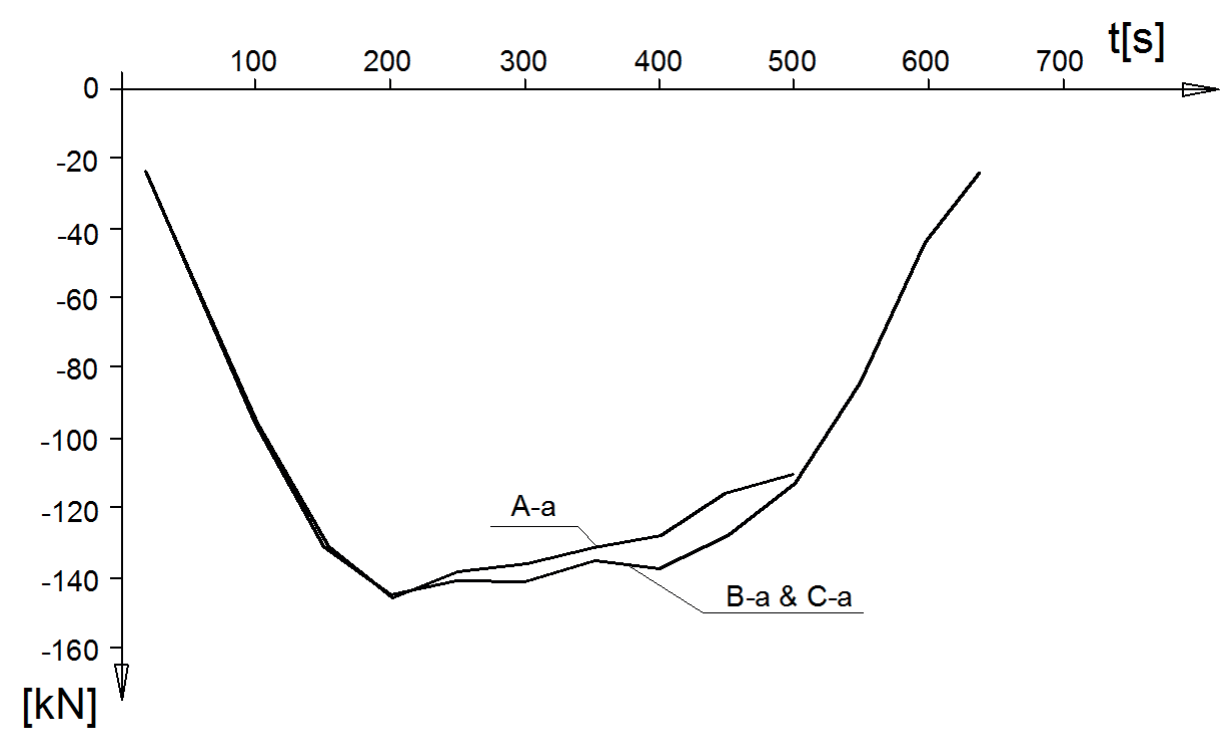

Figure 7. The relationship between steel temperature and the values of the axial force induced by the fire in the girt of the frame under consideration; results obtained for $\gamma-\gamma$ cross-section and scenario "a"

Rycina 7. Zależności pomiędzy temperaturą stali a wartościami siły osiowej generowanej w pożarze w ryglu ramy rozpatrywanej w przykładzie. Wyniki uzyskano dla przekroju $\gamma-\gamma$ i sytuacji projektowej „a”

Source: Own elaboration.

Źródło: Opracowanie własne.

\section{Joint damage patterns during a fire}

Another area where the tested frame structure behaved differently during a fire was how the hot joint was getting damaged. These different damage patterns were produced by the use of stiffening ribs, or lack thereof, in the joint. As shown in figure 9, in the frame with joints " $\mathrm{A}$ " and no web stiffeners, failure occurred as a result of buckling instability of the intermediate column at the lower girt line, which immediately caused both column flanges to become locally unstable.

The reliable model of the fire-induced damage of joint " $B$ " featuring horizontal web stiffeners at both the upper and lower beam flanges proved completely different from the previous one. Here, at a much higher steel temperature, the end column was seen to lose its local stability at the lower beam flange (fig. 10a). The joint featuring an intermediate column damaged in a slightly different way, with instability at the lower line of the left girt being observed in this case (fig. 10b).

\section{Sposoby zniszczenia węzła w pożarze}

Kolejnym czynnikiem różnicującym zachowanie się badanego ustroju ramowego w warunkach pożaru jest zaobserwowany sposób niszczenia się rozgrzanego węzła. Sposób ten determinowany jest przez zastosowane w węźle żebra usztywniające lub ewentualnie przez ich brak. Jak pokazano na rycinie $9, \mathrm{w}$ ramie z zastosowanymi węzłami typu "A" z nieużebrowanymi środnikami słupów wyczerpanie nośności nastąpiło wskutek utraty stateczności środnika słupa pośredniego w poziomie dolnych pasów rygli, co natychmiast pociągnęło za sobą lokalną niestateczność obydwu pasów tego słupa.

Miarodajny model zniszczenia w pożarze węzła typu "B”, z zastosowanymi żebrami poziomymi usztywniającymi środniki słupów w poziomie górnych i dolnych pasów rygli, okazał się całkowicie odmienny od poprzedniego. Tym razem, przy znacząco już wyższej temperaturze stali, w przypadku słupa skrajnego zaobserwowano lokalną utratę stateczności pasa tego słupa 
Joint damage patterns similar to those presented in figure 10 were also recorded when joints " $C$ " were used in the examined substructure. These are shown in figure 11. w poziomie dolnego pasa rygla (ryc. 10a). Nieco inaczej przebiegało zniszczenie węzła zawierającego słup pośredni. W tym przypadku odnotowano utratę stateczności dolnego pasa lewego rygla (ryc. 10b).

Sposoby zniszczenia węzłów, analogiczne do tych zaprezentowanych na rycinie 10, uzyskano także w przypadku zastosowania w rozpatrywanym podukładzie ramowym węzłów typu "C". Pokazano je na rycinie 11.

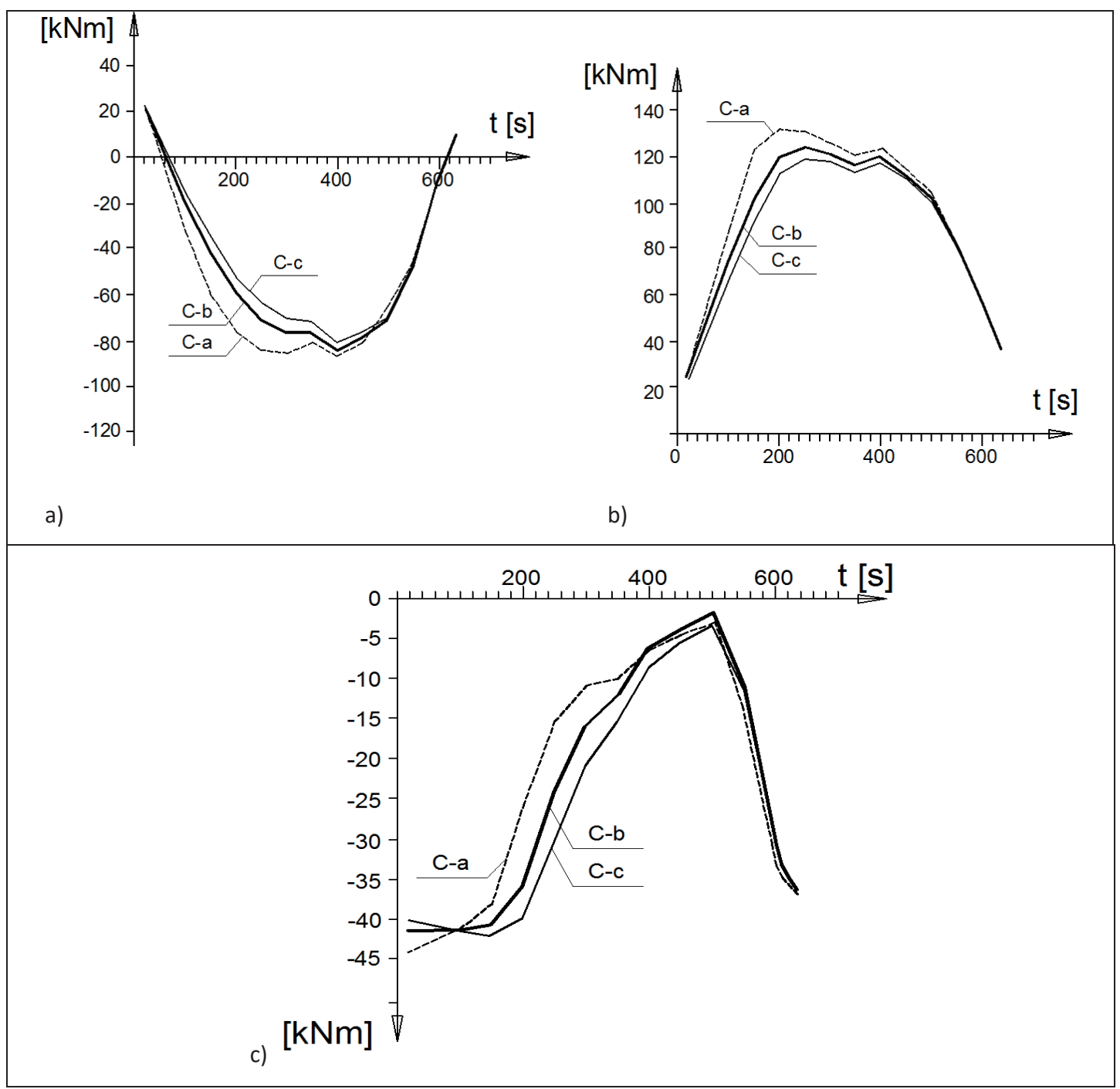

Figure 8. The relationship between steel temperature and the values of bending moments induced by the fire in joint "C $\mathrm{C}$ " of the frame under consideration, in scenarios "a", "b" and "c"; results obtained for a) $\alpha-\alpha$ cross-section b) $\beta-\beta$ cross-section c) $\gamma-\gamma$ cross-section, respectively

Rycina 8. Zależności pomiędzy temperaturą stali a wartościami momentów zginających generowanych w pożarze w węźle typu „C" ramy rozpatrywanej w przykładzie w kolejnych sytuacjach projektowych; „a”, „b" i „c". Wyniki uzyskane odpowiednio: a) w przekroju $\alpha-\alpha$ b) w przekroju $\beta-\beta$ c) w przekroju $\gamma-\gamma$ Source: Own elaboration.

Źródło: Opracowanie własne. 


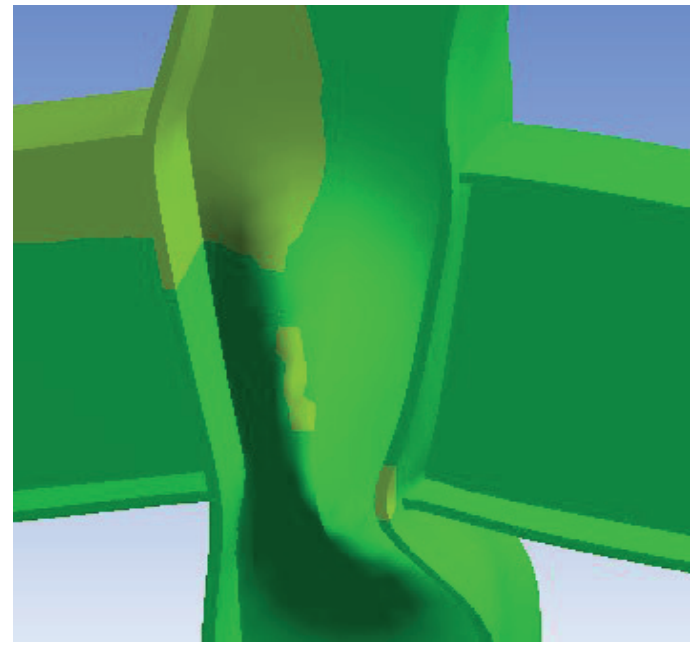

Figure 9. Local instability of the column web at the lower beam flanges as a fire-induced damage pattern for joint " $\mathrm{A}$ "

Rycina 9. Lokalna niestateczność środnika słupa pośredniego w poziomie dolnych pasów rygli jako model zniszczenia w warunkach pożaru miarodajny dla węzła typu "A"

Source: Own elaboration.

Źródło: Opracowanie własne.

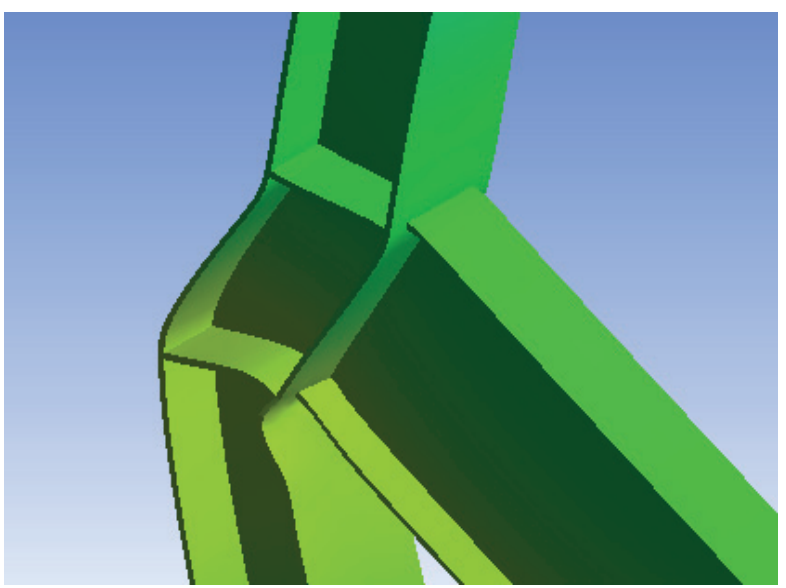

a)

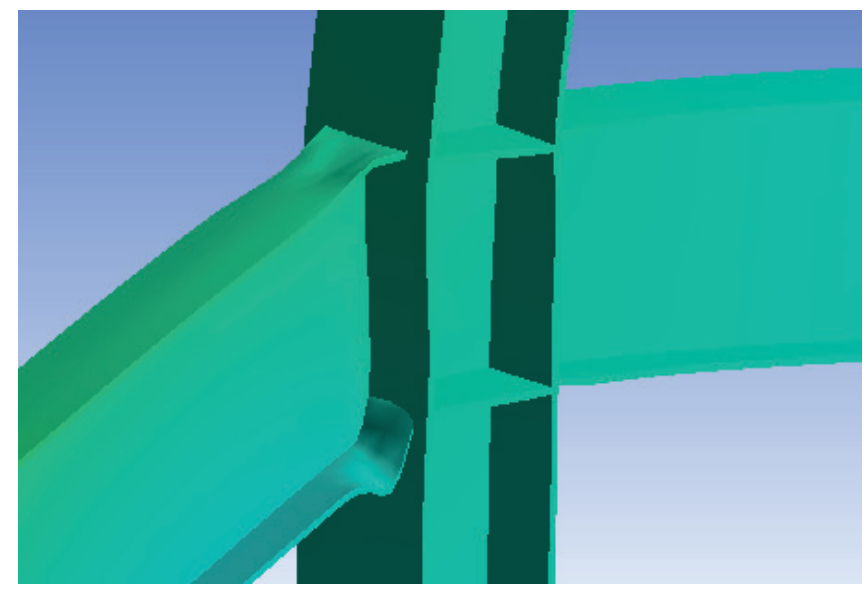

b)

Figure 10. Fire-induced damage patterns for joint " $B$ " as regards: a) end columns b) intermediate columns

Rycina 10. Modele zniszczenia w warunkach pożaru miarodajne dla węzłów typu „B": a) w przypadku słupa skrajnego b) w przypadku słupa pośredniego

Source: Own elaboration.

Źródło: Opracowanie własne.

\section{Final remarks}

The analyses presented in this paper build on broader research conducted by the authors to identify the potential patterns for the redistribution of internal forces, as found in load-bearing steel structures during a fire. The results of such previous studies have been published, e.g. in a conference report entitled Recent progress in steel and composite structures, Proceedings of the $13^{\text {th }}$ International Conference on Metal Structures [5]. The numerical simulations results, as described above, support the view that different designs of frame joints, which translate into their varying stiffness, can produce different

\section{Uwagi końcowe}

Rozważania prezentowane w niniejszej pracy stanowią kontynuację szerszych badań prowadzonych przez autorów w celu rozpoznania potencjalnie możliwych schematów redystrybucji sił przekrojowych realizowanej w ogarniętych pożarem stalowych ramowych ustrojach nośnych. Wcześniejsze wyniki tych prac były publikowane między innymi w materiałach pokonferencyjnych pt. Recent progress in steel and composite structures, Proceedings of the $13^{\text {th }}$ International Conference on Metal Structures [5]. Przytoczone powyżej rezultaty symulacji numerycznej potwierdzają przekonanie, że różna konstrukcja węzłów ramy, przekładająca się w konsekwencji na ich różną 
fire-induced damage patterns. Nevertheless, this does not necessarily mean that the analysed frame exhibits diverse response patterns when exposed to a fire. On the one hand, bending moments, which are generally dominant in the girt prior to the fire, first gradually start losing their importance as the fire progresses, only to regain their leading role when the temperature becomes sufficiently high. On the other hand, the bending moments in the frame columns, which usually tend to be insignificant when there is no fire, first rise as a result of the increased compressive axial force exerted on the girts, only to become weak again when that force diminishes. While different joint designs share a similar general pattern of the redistribution of internal forces, there might be some important differences in terms of the joint-specific critical temperature associated with the fire resistance limit state achieved by the analysed frame. Such differences were observed for joints " $A$ ", for which that temperature proved to be much lower compared to joints " $\mathrm{B}$ " or " $\mathrm{C}$ ", due to their significant initial flexibility. As a result, such joints could not fully go through all stages of the internal force redistribution process, which was easily achieved by similar frames with more rigid joints. The simulation performed by the authors has also demonstrated that the initial differences in susceptibility to horizontal deformations were not significant for the expected response of the examined frame to fire exposure. Even though such differences in susceptibility during initial stages of the fire produce fairly significant differences in the correlation between the steel temperature reached by frame components and the internal forces generated in such components at specific temperatures, they quickly lose their importance as the fire progresses. This is because the individual frame components are losing their load-bearing capability and, consequently, their flexural stiffness.

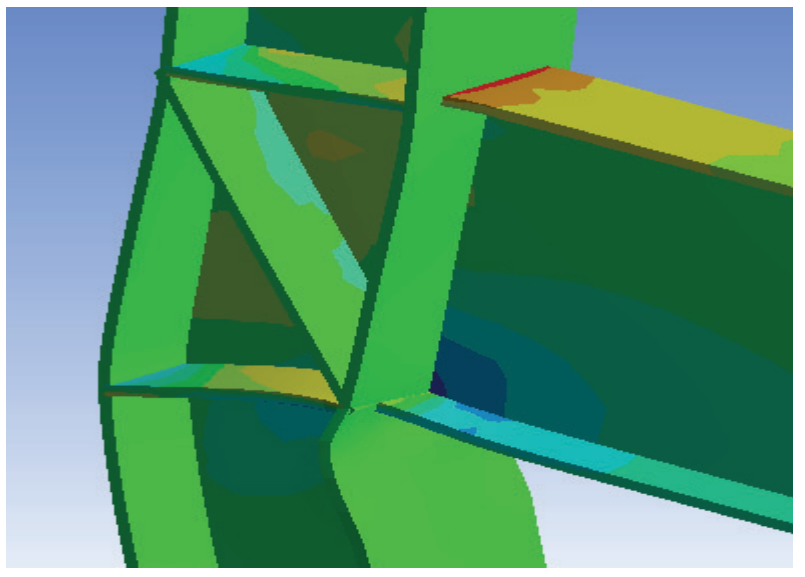

a) sztywność, może skutkować w warunkach pożaru realizacją różniących się wzajemnie modeli zniszczenia. Nie musi to jednak wcale oznaczać generowania się w pożarze odmiennych schematów odpowiedzi badanej ramy na ekspozycję pożarową. Z jednej strony momenty zginające $z$ reguły dominujące $w$ ryglu przed zainicjowaniem pożaru, w czasie jego trwania najpierw stopniowo tracą na znaczeniu, aby przy odpowiednio wysokiej temperaturze odzyskać swoją wiodącą rolę. Z drugiej strony momenty zginające słupy ramy, na ogół nieznaczne w sytuacji, gdy nie ma pożaru, najpierw intensyfikują się wskutek wzmożonego oddziaływania siły osiowej ściskającej rygle, aby w końcu ulec z powrotem osłabieniu, gdy siła ta traci na znaczeniu. Pomimo podobnego dla różnych wariantów konstrukcji węzłów ogólnego schematu realizacji redystrybucji sił przekrojowych istotnie różna co do wartości może okazać się specyfikowana przy założeniu zastosowania tych węzłów temperatura krytyczna kojarzona z osiągnięciem przez analizowaną ramę stanu granicznego nośności ogniowej. Tego typu różnicę odnotowano w przypadku zastosowania węzłów typu „A", dla których - z uwagi na ich dużą początkową podatność - temperatura ta okazała się znacząco niższa niż to miało miejsce po zastosowaniu węzłów typu „B" lub typu „C". Skutkiem tej różnicy był między innymi brak możliwości pełnej realizacji wszystkich etapów redystrybucji sił przekrojowych, z łatwością osiąganych przez analogiczną ramę z węzłami o większej sztywności. Przeprowadzona symulacja pokazała również, że w prognozowanej odpowiedzi badanej ramy na ekspozycję pożarową istotnego znaczenia nie ma także początkowe zróżnicowanie jej podatności na ewentualne deformacje poziome. Rozbieżności w tego rodzaju podatności w początkowej fazie pożaru determinują co prawda dość znaczące zróżnicowanie zależności pomiędzy temperaturą stali osiąganą w elementach ramy $i$ indukowanymi $w$ tych elementach i w tej temperaturze siłami przekrojowymi, niemniej jednak w dalszym przebiegu pożaru tracą one szybko na znaczeniu. Dzieje się tak ze względu na coraz bardziej zaawansowaną redukcję nośności poszczególnych elementów ramy i towarzyszące jej postępujące osłabienie ich sztywności giętnej.

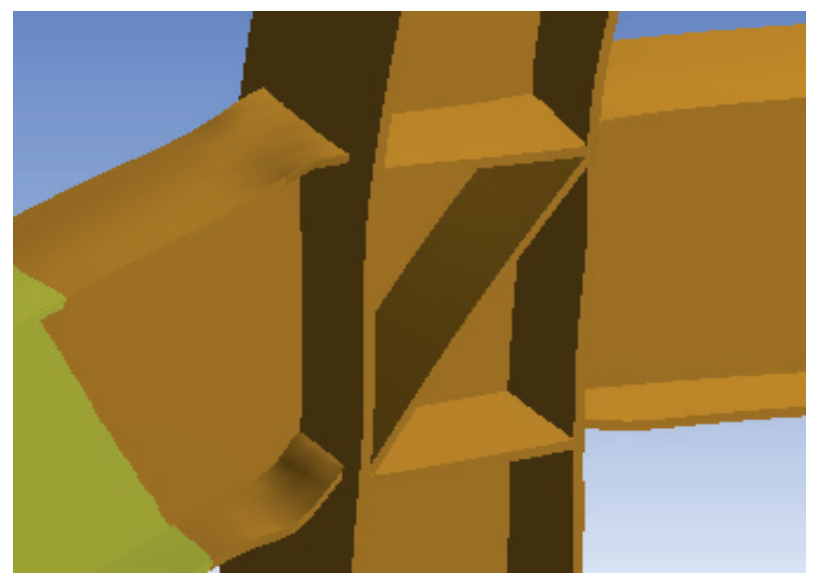

b)

Figure 11. Fire-induced damage patterns for joint "B" as regards: a) end columns b) intermediate columns

Rycina 11. Modele zniszczenia w warunkach pożaru miarodajne dla węzłów typu „B”: a) w przypadku słupa skrajnego b) w przypadku słupa pośredniego

Source: Own elaboration.

Źródło: Opracowanie własne. 


\section{Literature / Literatura}

[1] El-Rimawi J.A., Burgess I.W., Plank R.J., Studies of the behaviour of steel subframes with semi-rigid connections in fire, "Journal of Constructional Steel Research" 1999, 49, 83-98.

[2] Liu J., Jána T., Wald F., Internal forces in the structure during fire test, w: Proceedings of the 7th European Conference on Steel and Composite Structures “Eurosteel 2014", R. Landolfo, F.M. Mazzolani (red.), Napoli, Italy, September 10-12, 2014, abstract 801-803, article - pen-drive, 6 pages

[3] EN 1993-1-2. 2005. Eurocode 3: Design of steel structures. Part 1-2: General rules. Structural fire design.

MARIUSZ MAŚLAK, PH.D., D.SC., PROF. CUT - Associate Professor at the Department of Metal Structures of the Faculty of Civil Engineering, the Cracow University of Technology. His focus areas are the development, maintenance and verification of the safety of various types of steel load-bearing structures, including in particular the behaviour of such structures when exposed to fire. A member of the International Association for Fire Safety Science (IAFSS). A member of the Technical Committee 3 (TC3): "Fire Safety" of the European Convention for Constructional Steelwork (ECCS) representing Poland, and also a member of the Technical Committee CEN TC 250/SC3: "Evolution Group Eurocode 3, Part 1-2". Between 2010 and 2014 he was a member of the Management Committee of the International Research Project COST TU0904 "Integrated Fire Engineering and Response". A member of the Management Committee of the International Research Project COST TU1402 "Quantifying the Value of Structural Health Monitoring". A head of the project N N506 243938 funded by the Polish Ministry of Science and Higher Education called "Measures for safety and their interrelations in the accidental design situation of a fully developed fire" (including between 2010 and 2014).

PIOTR WOŹNICZKA, PH.D. - licensed construction designer. Assisstant professor at the Department of Metal Structures of the Faculty of Civil Engineering, the Cracow University of Technology. Currently, he delas with the issues of modelling complex steel load-bearing structures' response to fire exposure.
[4] Maślak M., Pazdanowski M., Woźniczka P., Influence of joint stiffness on the behavior of steel bearing frame under fire conditions, w: Proceedings of the 8th European Conference on Steel and Composite Structures “Eurosteel 2017", J. Jönsson (red.), Copenhagen, Denmark, September 13-15, 2017, article - pen-drive, 10 pages.

[5] Maślak M., Pazdanowski M., Snela M., Redistribution of internal forces generated in a steel frame structure with flexible joints when exposed to a fire, w: Recent progress in steel and composite structures, Proceedings of the 13th International Conference on Metal Structures (ICMS 2016), M. Giżejowski, A. Kozłowski, J. Marcinowski, J. Ziółko (red.), Zielona Góra, Poland, June 15-17, 2016, CRC Press/Balkema, Leiden, The Netherlands, abstract pp. 136-137, article - CD 315-322.

DR HAB. INŻ. MARIUSZ MAŚLAK, PROF. PK - profesor nadzwyczajny w Katedrze Konstrukcji Metalowych na Wydziale Inżynierii Lądowej Politechniki Krakowskiej. Zajmuje się kształtowaniem, utrzymaniem i weryfikacją stanu bezpieczeństwa różnego typu stalowych ustrojów nośnych ze szczególnym uwzględnieniem zachowania się tego typu konstrukcji w warunkach ekspozycji ogniowej. Członek International Association for Fire Safety Science (IAFSS). Z ramienia Polski członek Technical Committee 3 (TC3): „Fire Safety” przy European Convention for Constructional Steelwork (ECCS), a także członek Komitetu Technicznego CEN TC 250/SC3: „Evolution Group Eurocode 3, Part 1-2”. W latach 2010-2014 członek Komitetu Zarządzającego Międzynarodowego Projektu Badawczego COST TU0904 „Integrated Fire Engineering and Response”. Od roku 2014 członek Komitetu Zarządzającego Międzynarodowego Projektu Badawczego COST TU1402 "Quantifying the Value of Structural Health Monitoring. Kierownik grantu badawczego własnego N N506 243938 „Miary bezpieczeństwa i ich wzajemne relacje w wyjątkowej sytuacji projektowej pożaru rozwiniętego" (również w latach 2010-2014).

DR INŻ. PIOTR WOŹNICZKA - uprawniony projektant budowlany. Adiunkt naukowo-badawczy w Katedrze Konstrukcji Metalowych na Wydziale Inżynierii Lądowej Politechniki Krakowskiej. Zajmuje się problematyką modelowania odpowiedzi złożonych stalowych ustrojów nośnych na oddziaływanie pożarowe. 